\title{
Bio-inspired porous antenna-like nanocube/nanowire heterostructure as ultra-sensitive cellular interfaces
}

\author{
Biao Kong ${ }^{1,2}$, Jing Tang ${ }^{1}$, Zhangxiong $\mathrm{Wu}^{2}$, Cordelia Selomulya ${ }^{2}$, Huanting Wang ${ }^{2}$, Jing Wei ${ }^{2}$, \\ Yongcheng Wang ${ }^{1}$, Gengfeng Zheng ${ }^{1}$ and Dongyuan Zhao ${ }^{1,2}$
}

In this study, an unconventional antenna-like heterostructure comprised of arrays of nanoporous Prussian blue (PB) nanocube heads $/ \mathrm{TiO}_{2}$ nanowire $(\mathrm{NW})$ arms $\left(\mathrm{PB}-\mathrm{TiO}_{2}\right)$ is developed for efficient three-dimensional interfacial sensing of small molecules and cellular activities. Inspired by insect tentacles, which are comprised of both target recognition and signal transduction units, one-dimensional $\mathrm{TiO}_{2} \mathrm{NW}$ arrays are grown, followed by selective growth of nanoporous PB nanocubes on the tips of the NW arrays. Due to their high selectivity and bioaffinity toward cells, long biostability under a cell culture adhesion condition (up to $108 \mathrm{~h}$ ) is obtained, and with its inherent bio-mimetic enzymatic activity, the obtained nanoporous PB nanocubes (head segment) serve as robust substrates for site-selective cell adhesion and culture, which allows for sensitive detection of $\mathrm{H}_{2} \mathrm{O}_{2}$. Simultaneously, the single-crystalline $\mathrm{TiO}_{2} \mathrm{NWs}$ (arm segment) provide efficient charge transport for electrode substrates. Compared with PB-functionalized planar electrochemical interfaces, the $\mathrm{PB}^{-\mathrm{TiO}_{2}}$ antenna NW biointerfaces exhibit a substantial enhancement in electrocatalytic activity and sensitivity for $\mathrm{H}_{2} \mathrm{O}_{2}$, which includes a low detection limit $(\sim 20 \mathrm{~nm})$, broad detection range $\left(10^{-8}\right.$ to $\left.10^{-5} \mathrm{M}\right)$, short response time $(\sim 5 \mathrm{~s})$ and long-term biocatalytic activity (up to 6 months). The direct cultivation of HeLa cells is demonstrated on the $\mathrm{PB}-\mathrm{TiO}_{2}$ antenna NW arrays, which are capable of sensitive electrochemical recording of cellular activity in real time, where the results suggest the uniqueness of the biomimic $\mathrm{PB}-\mathrm{TiO}_{2}$ antenna $\mathrm{NWs}$ for efficient cellular interfacing and molecular recognition.

NPG Asia Materials (2014) 6, e117; doi:10.1038/am.2014.56; published online 1 August 2014

\section{INTRODUCTION}

Tentacles, which are the long, functional antennas of insects, provide unique and sensitive signal detection capabilities, such as olfaction, gestation and touching, which can guide the motion and functions of insects. ${ }^{1}$ The tip of a tentacle, known as the flagellum, is covered with ultra-sensitive olfaction sensing units that can detect specific molecular targets at extremely low concentrations (as low as several molecules per liter). The signal is then transferred through the trunk segment of the tentacle to the neuron networks. ${ }^{2}$ This dual-functional antenna structure of the insect tentacles demonstrates a unique modality for signal capture and transduction and could inspire new electrochemical sensor designs for enhanced sensitivity and performance. ${ }^{3}$ In particular, a heterostructure comprised of an ultra-sensitive redox unit and a rapid charge transport unit could substantially expand the capabilities of positioning and targeting of cell patterning and in detecting fluctuations and functions of target molecules at an unprecedented level.

Numerous cellular functions are closely correlated with small molecules, such as $\mathrm{O}_{2},{ }^{4}$ glucose, ${ }^{5}$ glutathione, ${ }^{6} \mathrm{NO},{ }^{7} \mathrm{CO}^{8}$ and $\mathrm{H}_{2} \mathrm{O}_{2},{ }^{9}$ for enzymatic co-factors, signaling and expression. Among them, $\mathrm{H}_{2} \mathrm{O}_{2}$ is an important reactive oxygen species that can diffuse across cell membranes and lead to oxidative protein modification. ${ }^{10}$ Prussian blue (PB) is known as an artificial enzyme peroxidase with porous frameworks, which can efficiently reduce $\mathrm{H}_{2} \mathrm{O}_{2}$ at extremely rapid catalytic rates with low overpotentials. ${ }^{11}$ For example, molecularly imprinted $\mathrm{PB}$ films ${ }^{12}$ and $\mathrm{PB} /$ carbon nanotubes ${ }^{13}$ have been used for biosensing because their low overpotentials can exclude interferences from coexisting substances, such as ascorbic acid (AA), uric acid and glucose. However, previous work predominantly used PB nanocrystals that had been post-modified on flat substrates, and thus, only a limited number of crystal faces were exposed to electrolytes, which resulted in lower electrochemical responses. In addition, a relatively large background current still existed due to the secondary electrochemical reactions that occurred on the planar electrode surface. ${ }^{14}$ Although bio-mimetic enzyme-based electrical sensors are attractive tools, their use on a robust lab-on-a-chip platform with fast, sensitive and stable three-dimensional (3D) porous interfaces for localized real-time, long-term monitoring of cellular activities and physicochemical changes have not been demonstrated. ${ }^{15-19}$

Inspired by insect tentacles, herein, we developed an unconventional antenna-like heterostructure based on direct growth of porous

\footnotetext{
${ }^{1}$ Laboratory of Advanced Materials, Department of Chemistry, Shanghai Key Laboratory of Molecular Catalysis and Innovative Materials, Fudan University, Shanghai, China and 2Department of Chemical Engineering, Monash University, Clayton, Victoria, Australia

Correspondence: Professor G Zheng or Professor D Zhao, Laboratory of Advanced Materials, Department of Chemistry, Shanghai Key Laboratory of Molecular Catalysis and Innovative Materials, Fudan University, Shanghai 200433, China.

E-mail: gfzheng@fudan.edu.cn or dyzhao@fudan.edu.cn
}

Received 5 January 2014; revised 5 April 2014; accepted 18 May 2014 
PB nanocube heads on the tips of $\mathrm{TiO}_{2}$ nanowire (NW) arms, which can be used for 3D interface recognition and biosensing. Singlecrystalline $\mathrm{TiO}_{2}$ NWs are first hydrothermally grown on conducting substrates, followed by the direct growth of nanoporous $\mathrm{PB}$ nanocubes on the tips of the $\mathrm{TiO}_{2} \mathrm{NW}$ arrays via an etching and seed-assisted process (Figure 1, Supplementary Figure S1). The PB nanocubes (head segment) provide site-selective cell adhesion and growth, a large surface area for catalysis and a high sensitivity and selectivity for $\mathrm{H}_{2} \mathrm{O}_{2}$. The semiconductor $\mathrm{TiO}_{2} \mathrm{NW}$ arms offer fast charge transport from the $\mathrm{PB}$ redox centers to the underlying electrode surface due to the excellent electron mobility of $\mathrm{TiO}_{2}$, the continuous one-dimensional charge transport channels ${ }^{20,21}$ and the low background electrical current noise. As a proof-of-concept design, the bio-mimetic $\mathrm{PB} / \mathrm{TiO}_{2}$ antenna NW heterostructures exhibit high selectivity and bioaffinity toward living cells and excellent biostability under cell culture adhesion conditions (up to $108 \mathrm{~h}$ ). Compared with that of PB-functionalized planar electrochemical interfaces, the electrocatalytic activity on $\mathrm{H}_{2} \mathrm{O}_{2}$ produced by HeLa cells is enhanced by $\sim 550$ times on the $\mathrm{PB}-\mathrm{TiO}_{2}$ antenna NWs, which exhibits a high sensitivity of $\sim 20 \mathrm{nM}$, broad detection range from $10^{-8}$ to $10^{-5} \mathrm{M}$ and a fast response time that is within $5 \mathrm{~s}$.

\section{MATERIALS AND METHODS}

\section{Materials}

AA, dopamine, uric acid and Phorbol 12-myristate-3-acetate (PMA) were purchased from Sigma Chemical Co. (St Louis, MO, USA). Tetrabutyl titanate, hydrochloric acid $(37 \mathrm{wt} \%), \mathrm{K}_{4} \mathrm{Fe}(\mathrm{CN})_{6} \cdot 3 \mathrm{H}_{2} \mathrm{O}, \mathrm{K}_{3}\left[\mathrm{Fe}(\mathrm{CN})_{6}\right] \cdot 3 \mathrm{H}_{2} \mathrm{O}, \mathrm{NaNO}_{2}$, $\mathrm{Na}_{2} \mathrm{SO}_{3}$ and $\mathrm{H}_{2} \mathrm{O}_{2}$ were purchased from Sinopharm Chemical Reagent Co., Ltd. (Shanghai, China). Dulbecco's Modified Eagle's medium (high glucose), RPMI-1640, fetal calf serum, penicillin G, streptomycin and trypsinase were purchased from GIBCO BRL (Grand Island, NY, USA). The fluorine-doped tin oxide-coated glass $\sim 14 \Omega$ per square substrates was purchased from Wuhan
Ge-ao Ltd. (Wuhan, China). Other reagents were of analytical grade and used as purchased. All the solutions were prepared by Milli-Q water (Merck KGaA, Darmstadt, Germany) and deaerated with high-purity nitrogen before experiments.

\section{Methods}

The $\mathrm{PB}-\mathrm{TiO}_{2}$ NWs were prepared by a two-step interfacial growth method. $\mathrm{TiO}_{2}$ NWs were first grown on the fluorine-doped tin oxide-coated glass ( $\sim 14 \Omega$ per square substrates, Wuhan Ge-ao Ltd.) by a hydrothermal method, as described previously. ${ }^{22,23}$ Then, the $\mathrm{TiO}_{2} \mathrm{NWs}$ glass substrates were placed within a 125 -ml glass bottle, containing $80 \mathrm{ml}$ of HCL $(0.005 \mathrm{M})$ and $136 \mathrm{mg}$ of $\mathrm{K}_{3}\left[\mathrm{Fe}(\mathrm{CN})_{6}\right] \cdot 3 \mathrm{H}_{2} \mathrm{O}$, and stirred for $30 \mathrm{~min}$. The bottle was placed in an oven at $85^{\circ} \mathrm{C}$ for $24 \mathrm{~h}$ to form the $\mathrm{PB}$ nanocrystal seeds. The $\mathrm{TiO}_{2} \mathrm{NWs}$ with $\mathrm{PB}$ seeds were washed with neat ethanol and water thoroughly to remove the adsorbed nanocrystals on the $\mathrm{TiO}_{2}$ NWs surface. To form the PB hierarchical structure on $\mathrm{TiO}_{2} \mathrm{NWs}, \mathrm{K}_{4} \mathrm{Fe}(\mathrm{CN})_{6} \cdot 3 \mathrm{H}_{2} \mathrm{O}(125 \mathrm{mg})$ was first added to a $\mathrm{HCl}$ solution $(0.05 \mathrm{M}, 80 \mathrm{ml})$ under stirring for $30 \mathrm{~min}$. Then, the $\mathrm{TiO}_{2}-\mathrm{PB}$ seeds substrate was slowly immersed into the above mixture. After that, the container was placed into an oven and heated at $85^{\circ} \mathrm{C}$ for $6-18 \mathrm{~h}$. The obtained PB-armed $\mathrm{TiO}_{2}$ NWs was taken from the container, washed with deionized water and dried in a vacuum oven at $70{ }^{\circ} \mathrm{C}$ for $12 \mathrm{~h}$.

\section{RESULTS AND DISCUSSION}

Fabrication of $\mathrm{PB}^{-\mathrm{TiO}_{2}}$ antenna NW heterostructures

The controlled synthesis of the $\mathrm{PB}-\mathrm{TiO}_{2}$ antenna NW heterostructures is performed in two steps. One-dimensional $\mathrm{TiO}_{2} \mathrm{NWs}$ are first hydrothermally grown on fluorine-doped tin oxide substrates, followed by a seed-induced growth of $\mathrm{PB}$ nanocubes on the tips of the pre-formed $\mathrm{TiO}_{2}$ NWs (Experimental section in the Supplementary Information). Scanning electron microscopy images show that the diameters and densities of the $\mathrm{TiO}_{2} \mathrm{NW}$ arrays are well tuned by the acidity of the precursor solution. ${ }^{22,23}$ Increasing the solution acidity

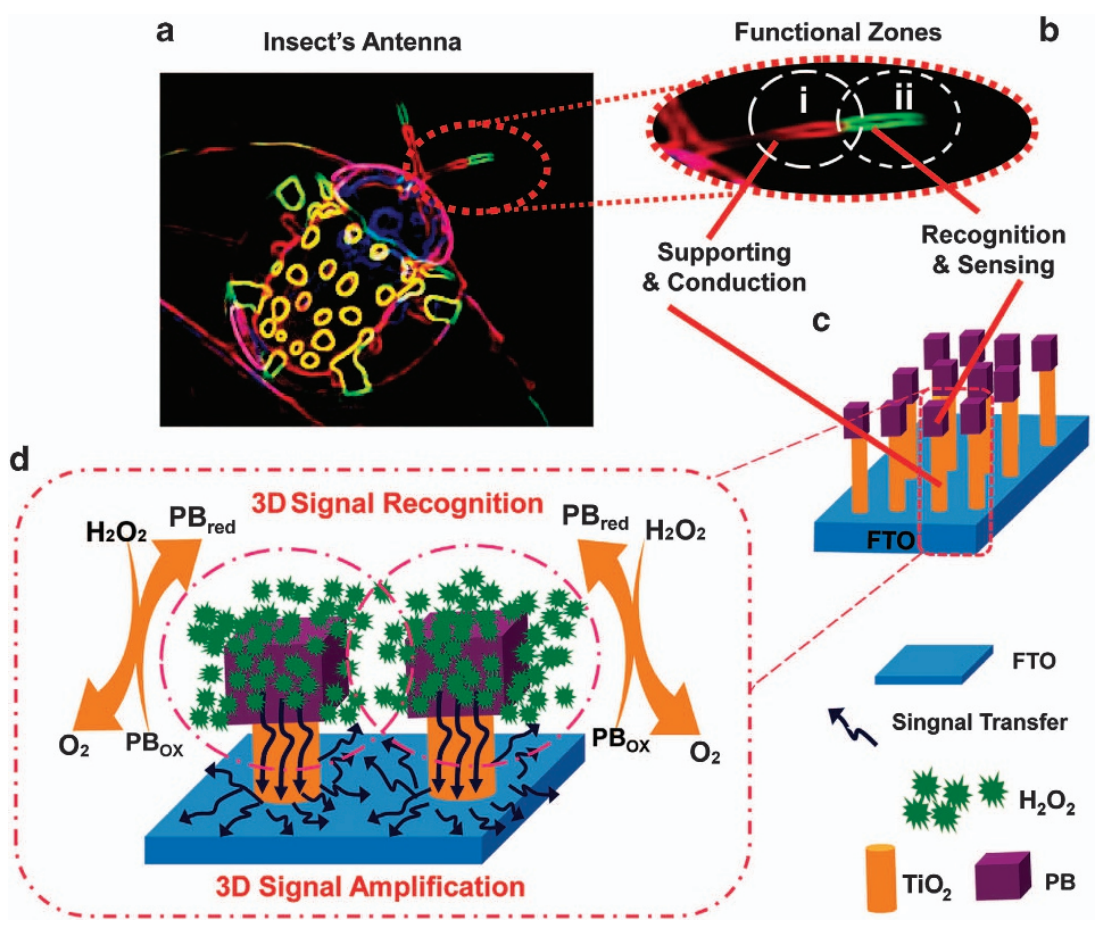

Figure 1 Schematic illustration of three-dimensional (3D) signal recognition and amplification based on porous bio-mimetic antenna nanowire arrays. (a) A typical drawing of an insect's antennas according to their different functional zones. (b) Enlarged drawing of an antenna with (i) supporting and conduction and (ii) recognition and sensing zones. (c) Designed nanoporous bio-mimetic antenna arrays growth on a conducting substrate. (d) 3D signal recognition and amplification based on the nanoporous bio-mimetic antenna arrays. 
leads to a decrease in both diameter and density (Figure 2a, Supplementary Figures S2a and c). Subsequently, the tips of the $\mathrm{TiO}_{2}$ NWs are etched using diluted HCL, followed by hydrothermal growth of PB nanocubes (Supplementary Figure S1). ${ }^{24}$ At low $\mathrm{TiO}_{2}$ NW densities, each NW tip is covered with a cluster of nanocubes, which substantially exceed the diameter of the corresponding NW arms (Supplementary Figure S2b). At intermediate NW densities, the measured average diameter and interspacing between adjacent NWs are $\sim 100$ and $150 \mathrm{~nm}$, respectively (Figure $2 \mathrm{a}$ ). The nanocubes with well-defined shapes are grown from each $\mathrm{TiO}_{2} \mathrm{NW}$ (Figure 2b, Supplementary Figure S3). Cross-sectional scanning electron microscopy images also clearly show the bio-mimetic antenna-like heterostructure formation (Figures $2 \mathrm{c}$ and d). Compared with bare $\mathrm{TiO}_{2}$ NWs, the NW tips are covered by a thin layer of PB nanocubes. The edge length of the nanocubes is calculated to be $\sim 150 \mathrm{~nm}$, which is similar to the average interspacing between adjacent $\mathrm{TiO}_{2} \mathrm{NWs}$. The top-view and side-view transmission electron microscopy (TEM) images show that the number of nanocubes and underlying $\mathrm{TiO}_{2}$ NWs are similar, which suggests that essentially, each NW tip serves as a growth base for individual nanocubes (Figures $2 \mathrm{e}$ and $\mathrm{f}$ ). This structure provides sufficient space surrounding the crystallized $\mathrm{PB}$ nanocubes while maintaining a close contact between the $\mathrm{PB}$ nanocubes with the $\mathrm{TiO}_{2} \mathrm{NW}$ bases. When the diameter and density of the $\mathrm{TiO}_{2}$ NWs are further increased, the interspacing between adjacent NWs is less than the average NW diameter. Thus, the nanocubes on the NW tips accumulate, which forms a multi-layered nanocube assembly (Supplementary Figure S2d). The heterostructure of the $\mathrm{PB}$ nanocube head/TiO $2 \mathrm{NW}$ arm is revealed by TEM
(Figure 2g, Supplementary Figure S4). The single $\mathrm{TiO}_{2} \mathrm{NWs}$ (Figures $2 \mathrm{~h}$ and $\mathrm{i}$ ) and single $\mathrm{PB}$ nanocubes (Figures $2 \mathrm{j}$ and $\mathrm{k}$ ) in the heterostructures are further characterized by high-resolution TEM (HRTEM). Both the HRTEM and selected area electron diffraction pattern (Figure 2l) demonstrate the crystallized characteristics of the $\mathrm{TiO}_{2}$ NWs and PB nanocrystals.

The crystal structure of the $\mathrm{PB}-\mathrm{TiO}_{2}$ antenna NW heterostructures is further examined by X-ray diffraction, which shows a combination of the diffraction peaks of $\mathrm{TiO}_{2}$ and $\mathrm{PB}$ (Figure 3a). No additional peaks other than those of fluorine-doped tin oxide substrates are observed, which indicates the high purity of the samples. Compared with pristine $\mathrm{TiO}_{2}$ NWs that have negligible absorption in the visible range, the ultraviolet-visible spectra of the $\mathrm{PB}_{-}-\mathrm{TiO}_{2}$ antenna NWs show a substantial absorption increase in the range of $500-900 \mathrm{~nm}$ with a maximum at $714 \mathrm{~nm}$, which corresponds to the inter-metal charge transfer bands from $\mathrm{Fe}^{2+}$ to $\mathrm{Fe}^{3+}$ in $\mathrm{PB}$ nanocrystals (Figure $3 \mathrm{~b}) .{ }^{25}$ The corresponding energy dispersive X-ray analysis of the $\mathrm{PB}-\mathrm{TiO}_{2} \quad \mathrm{NWs}$ shows clear $\mathrm{Fe}$ and $\mathrm{Ti}$ signals (Supplementary Figure S5). The growth of $\mathrm{PB}-\mathrm{TiO}_{2}$ antenna $\mathrm{NWs}$ is further demonstrated by the infrared spectra. In addition to the infrared absorption of pristine $\mathrm{TiO}_{2} \mathrm{NWs}$ centered at 3428 and $1628 \mathrm{~cm}^{-1}$, a new absorption band at $2095 \mathrm{~cm}^{-1}$ is observed for the $\mathrm{PB}-\mathrm{TiO}_{2}$ antenna NWs, which corresponds to the $\mathrm{C} \equiv \mathrm{N}$ stretching mode in the $\mathrm{Fe}^{\mathrm{II}}(\mathrm{C} \equiv \mathrm{N}) / \mathrm{Fe}^{\mathrm{III}}$ pair of $\mathrm{PB}$ nanocrystals (Figure 3c). ${ }^{26}$ Furthermore, the Raman spectrum of the $\mathrm{PB}-\mathrm{TiO}_{2}$ antenna NWs shows the characteristic band of $\mathrm{PB}$ at $2157 \mathrm{~cm}^{-1}$, which further confirms the successful incorporation of $\mathrm{PB}$ over $\mathrm{TiO}_{2} \mathrm{NWs}$ (Figure 3d). ${ }^{13}$
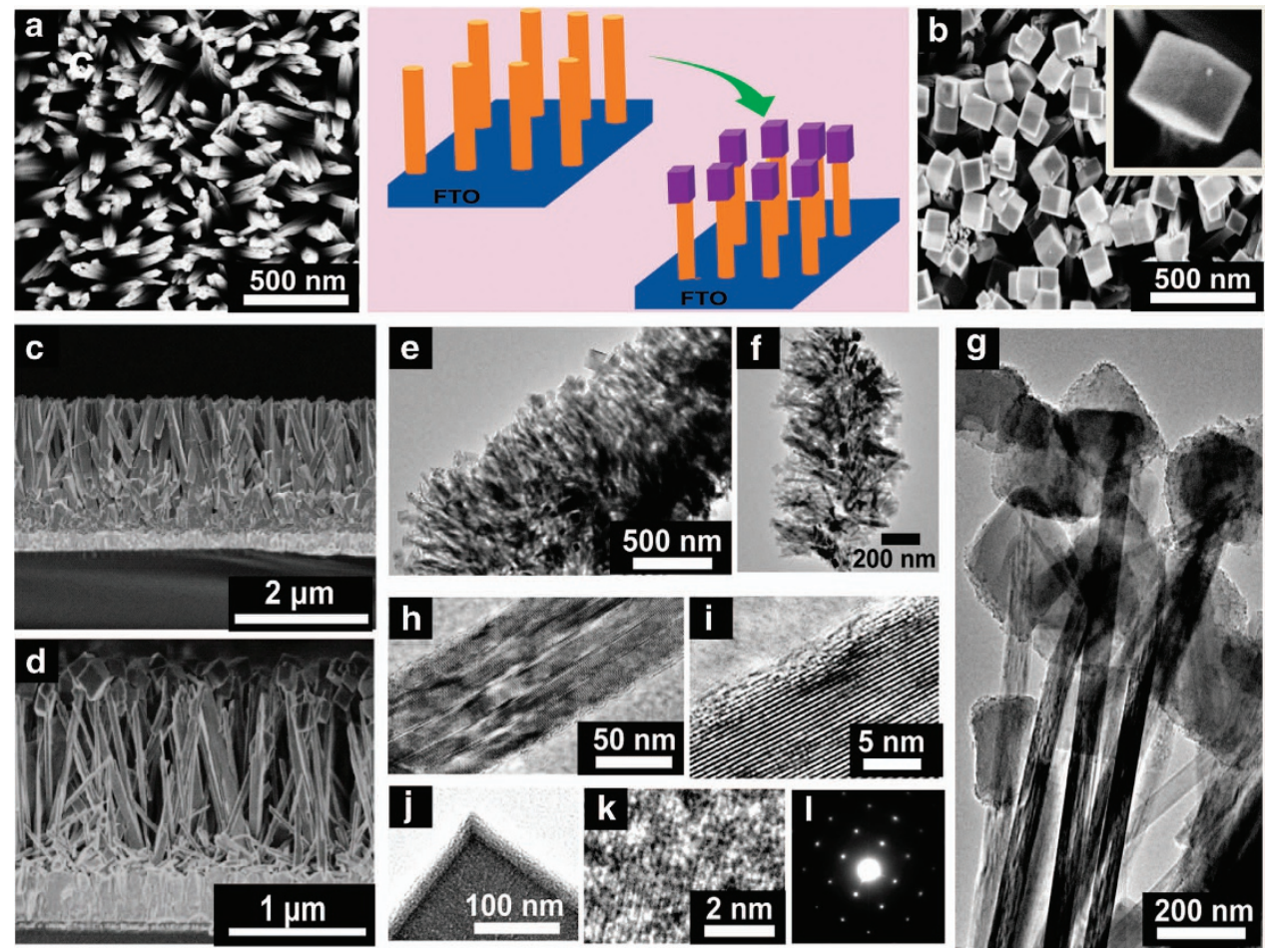

Figure 2 Synthesis and characterization of bio-mimetic antenna Prussian blue (PB)- $\mathrm{TO}_{2}$ heterostructure arrays. (a) Top-view scanning electron microscopy (SEM) images of the $\mathrm{TiO}_{2}$ nanowire (NW) arrays on fluorine-doped tin oxide (FTO)-coated glass substrates at an intermediate density. (b) Top-view SEM images of $\mathrm{PB}-\mathrm{TiO}_{2} \mathrm{NWs}$ at an intermediate density via an etching and seed growth method. (c,d) Side-view $\mathrm{SEM}$ images of (k) TiO 2 NW arrays and (I) $\mathrm{PB}-\mathrm{TiO}_{2} \mathrm{NW}$ arrays at an intermediate density. (e) Side-view, (f) top-view and (g) enlarged transmission electron microscopy (TEM) images of synthesized PB- $-\mathrm{TiO}_{2}$ NW arrays at an intermediate density, as in e. (h,i) High-resolution TEM (HRTEM) and enlarged HRTEM image of a single TiO ${ }_{2}$ NW. (j,k) HRTEM and enlarged HRTEM image of a single PB nanocube. (I) Selected area electron diffraction (SAED) pattern of a single PB nanocube. 
a

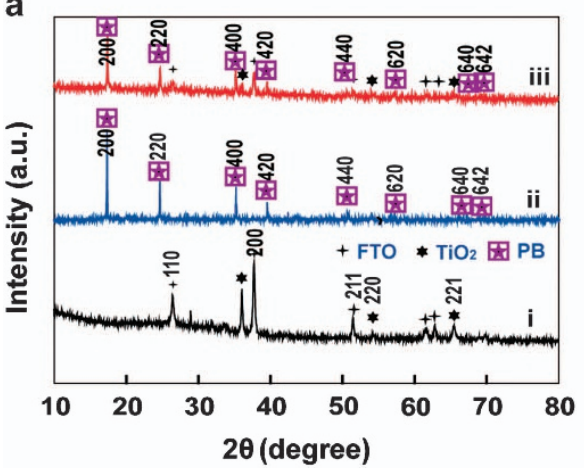

c

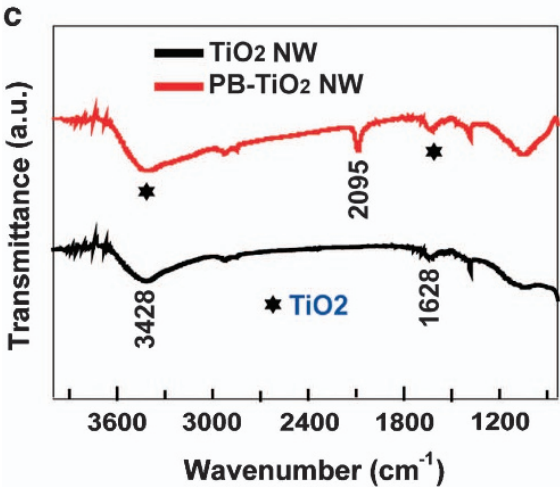

b

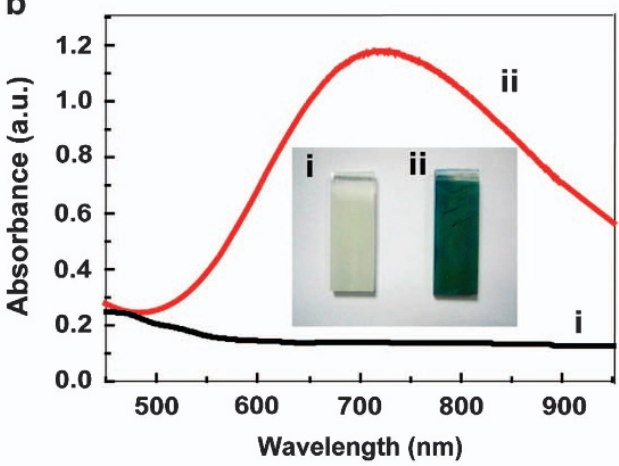

d

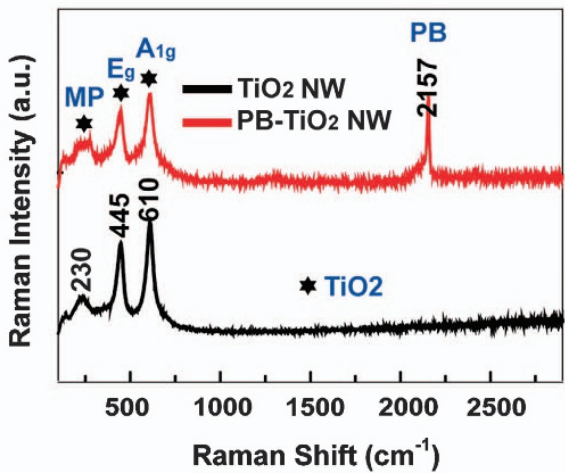

Figure 3 (a) X-ray diffraction spectrum of $\mathrm{TiO}_{2}$ nanowires (NWs), Prussian blue (PB) nanocraystals and $\mathrm{PB}^{-\mathrm{TiO}_{2}} \mathrm{NWs}$. The peaks of $\mathrm{PB}$, blank $\mathrm{TiO}_{2}$ and fluorine-doped tin oxide substrates are marked. (b) The ultraviolet-visible diffused reflectance spectrums of blank $\mathrm{TiO}_{2} \mathrm{NWs}_{\mathrm{N}}$ and $\mathrm{PB}-\mathrm{TiO} \mathrm{N}_{2} \mathrm{NWs}$. Inset: the corresponding images of blank $\mathrm{TiO}_{2} \mathrm{NWs}$ and $\mathrm{PB}-\mathrm{TiO}_{2} \mathrm{NWs}$. (c) Fourier transform infrared spectroscopy spectra of the $\mathrm{TiO}_{2} \mathrm{NWs}$ (black curve) and PB-TiO NWs (red curve). (d) Raman shift spectra of $\mathrm{TiO}_{2} \mathrm{NWs}$ (black curve) and $\mathrm{PB}-\mathrm{TiO}_{2} \mathrm{NWs}$ (red curve).

The synthesis mechanism of the proposed etching and seed-assisted process is as follows. First, the intermediate $\mathrm{PB}$ seed-modified $\mathrm{TiO}_{2}$ NWs are observed on the tips of pristine $\mathrm{TiO}_{2} \mathrm{NWs}$, in which the composite $\mathrm{TiO}_{2}$ NWs have identical close-packed cubic structures (Supplementary Figure S6). Thus, no clear phase separation occurs on the $\mathrm{TiO}_{2} \mathrm{NW}$ interfaces during the hydrothermal growth process. The removal of $\mathrm{PB}$ nanocrystals by an alkaline solution at room temperature for $5 \mathrm{~h}$ from the $\mathrm{PB}-\mathrm{TiO}_{2} \mathrm{NWs}$ increased the porous property on the top of the $\mathrm{TiO}_{2}$ NWs (Supplementary Figure S7), which suggests the existence of acid etching during the hydrothermal process. For comparison, the growth without PB seeds does not result in any nanocube structures on the tips of the $\mathrm{TiO}_{2} \mathrm{NWs}$ (Supplementary Figure S8). However, the growth with acid etching only and in the absence of seeds shows that no nanocube clusters formed on the $\mathrm{TiO}_{2}$ NWs during the hydrothermal process (Supplementary Figure S9); only sporadic PB nanocrystals are adsorbed on the surface of the $\mathrm{TiO}_{2}$ NWs.

\section{Electrochemical performance}

The electrochemical properties of the $\mathrm{PB}-\mathrm{TiO}_{2}$ antenna NW heterostructure are investigated by the cyclic voltammetry method. For comparison, the pristine $\mathrm{TiO}_{2}$ NWs are also measured under similar conditions. No redox peaks except for the capacitive current are observed for the pristine $\mathrm{TiO}_{2} \mathrm{NW}$ electrode, whereas the $\mathrm{PB}-\mathrm{TiO}_{2}$ antenna NW electrode has a pair of redox peaks at 0.23 and $0.18 \mathrm{~V}$ (Figure $4 \mathrm{a}$ ), which corresponds to the reversible conversion of PB to Prussian white. ${ }^{25}$ The scan rate dependency for the voltammetry profile of the $\mathrm{PB}-\mathrm{TiO}_{2}$ antenna NW electrode in the range $50-1000 \mathrm{mV} \mathrm{s}^{-1}$ is then presented (Figure 4b), in which the electrochemical stability of the $\mathrm{PB}^{-\mathrm{TiO}_{2}}$ antenna NWs is demonstrated by repeating cyclic voltammetry measurements at a scan rate of $50 \mathrm{mV} \mathrm{s}^{-1}$. There is no observable difference in either current level or peak positions for the cyclic voltammetry curves after 50 cycles (Figure 4c), which confirms the stable structure of the immobilized $\mathrm{PB}$ nanocubes on the $\mathrm{TiO}_{2} \mathrm{NW}$ tips.

The capability of using $\mathrm{PB}-\mathrm{TiO}_{2}$ antenna NWs as an amperometric sensing modality for $\mathrm{H}_{2} \mathrm{O}_{2}$ is further investigated because it is wellknown that the reduced form of $\mathrm{PB}$ exhibits a high catalytic activity for $\mathrm{H}_{2} \mathrm{O}_{2}$ reduction. ${ }^{27}$ During this process, $\mathrm{PB}$ acts as an electron transport mediator between the electrode and $\mathrm{H}_{2} \mathrm{O}_{2}$ in a solution. The presence of $\mathrm{H}_{2} \mathrm{O}_{2}$ (5 mM in phosphate buffer saline (PBS), $\mathrm{pH}$ of 6.0) leads to a clear increase in current density (corresponding to $\mathrm{H}_{2} \mathrm{O}_{2}$ reduction) at a lower overpotential (that is, $-50 \mathrm{mV}$ versus $\mathrm{Ag} / \mathrm{AgCl}$ ) (Figure $4 \mathrm{~d}$ ). The calculated electron transfer rate constant, $k_{s}$, is $5.72 \pm 0.05 \mathrm{~s}^{-1}$, which is much greater than that for most of the $\mathrm{H}_{2} \mathrm{O}_{2}$ electrodes reported previously, such as the ordered nanoporous niobium oxide film $\left(0.28 \mathrm{~s}^{-1}\right),{ }^{28} \mathrm{NaY}$ zeolite/glassy carbon electrode $\left(0.78 \pm 0.04 \mathrm{~s}^{-1}\right)^{29}$ and colloidal Au/carbon paste $\left(1.21 \pm 0.08 \mathrm{~s}^{-1}\right) .{ }^{30}$

\section{$\mathrm{PB}-\mathrm{TiO}_{2}$ antenna NW arrays for $\mathrm{H}_{2} \mathrm{O}_{2}$ sensing}

The sensor performance of $\mathrm{PB}-\mathrm{TiO}_{2}$ antenna NWs in detecting $\mathrm{H}_{2} \mathrm{O}_{2}$ is extensively investigated. Because coexisting molecular interferences, such as $\mathrm{AA}, \mathrm{O}_{2}$ and so on, may affect the electrochemical determination of $\mathrm{H}_{2} \mathrm{O}_{2}$, the bias potential should be prudently selected to optimize the cathodic current and sensitivity obtained at the $\mathrm{PB}-\mathrm{TiO}_{2}$ antenna NW electrodes. Amperometric experiments were performed to investigate the responses of $\mathrm{PB}-\mathrm{TiO}_{2}$ antennas from $\mathrm{H}_{2} \mathrm{O}_{2}$ at various potentials of $-0.10,-0.05,0.00,0.05$ and $0.10 \mathrm{~V}$ (versus $\mathrm{Ag} / \mathrm{AgCl}$ ). Several interference molecules, which included $\mathrm{O}_{2}, \mathrm{Na}_{2} \mathrm{SO}_{3}$, uric acid, 3,4-dihydroxyphenylacetic acid, $\mathrm{NaNO}_{2}$ and $\mathrm{AA}$, were tested 

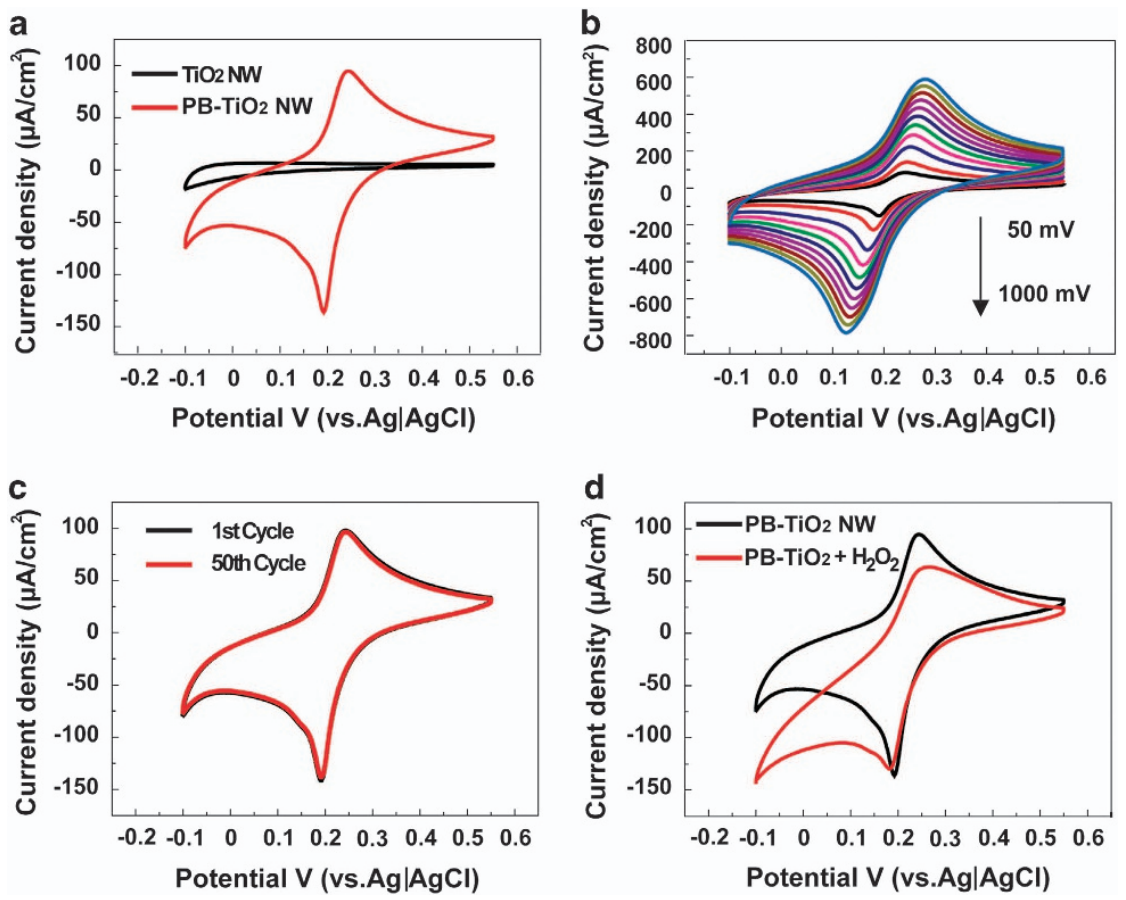

Figure 4 Electrochemical performance of bio-mimetic Prussian blue (PB)- $\mathrm{TiO}_{2}$ antenna arrays. (a) Cyclic voltammograms $(\mathrm{CVs})$ of the blank $\mathrm{TiO}_{2}$ nanowires (NWs) (black curve) and $\mathrm{PB}-\mathrm{TiO}_{2}$ NWs (red curve) in $\mathrm{N}_{2}$-saturated $0.05-\mathrm{M}$ phosphate buffer saline (PBS) solution ( $\mathrm{pH}$ of 6.0 ) at a scan rate of $50 \mathrm{mV} \mathrm{s}^{-1}$. $\mathrm{An} \mathrm{Ag} / \mathrm{AgCl}$ electrode was used as a reference electrode. (b) $\mathrm{CVs}$ of $\mathrm{PB}-\mathrm{TiO}_{2} \mathrm{NWs}$ in $\mathrm{N}_{2}$-saturated $0.05-\mathrm{M}$ PBS solution (pH of 6.0 ) at different scan rates: 50-1000 $\mathrm{mVs}^{-1}$ from the inside to the outside. (c) The CVs of the first cycle (black curve) and 50th cycle (red curve) of the PB-TiO $\mathrm{NWS}_{2}$ in the $\mathrm{N}_{2}$-saturated $0.05-\mathrm{M}$ PBS solution ( $\mathrm{pH}$ of 6.0 ) at a scan rate of $50 \mathrm{mVs}^{-1}$. (d) The $\mathrm{CVs}$ of a $\mathrm{PB}^{-\mathrm{TiO}_{2}} \mathrm{NWs}$ electrode in the $\mathrm{N}_{2}$-saturated $0.05-\mathrm{M}$ PBS solution ( $\mathrm{pH}$ of 6.0) in the absence (black curve) and presence of $5 \mathrm{~mm} \mathrm{H}_{2} \mathrm{O}_{2}$ (red curve) at a scan rate of $50 \mathrm{mV} \mathrm{s}^{-1}$.

(Figure 5a). In general, a low anodic current is obtained for the interference molecules at relatively negative potentials. For example, the ratio of anodic current between $\mathrm{H}_{2} \mathrm{O}_{2}$ to $\mathrm{AA}$ ( $0.1 \mathrm{~mm}$ each) increases from 6.8 to $55 \mathrm{~A}$ when the applied potential is reduced from 0.10 to $-0.05 \mathrm{~V}$ (versus $\mathrm{Ag} / \mathrm{AgCl}$ ), which increases the selectivity. ${ }^{31}$ Hence, $-0.05 \mathrm{~V}$ (versus $\mathrm{Ag} / \mathrm{AgCl}$ ) is selected as the optimized operational bias potential. In contrast, control experiments of pristine $\mathrm{TiO}_{2}$ NWs and $\mathrm{TiO}_{2}$ NWs post-modified with $\mathrm{PB}\left(\mathrm{TiO}_{2}\right.$ $\mathrm{NWs}+\mathrm{PB}$ ) do not show a similar high current signal or signal ratios, even at an applied potential of $-0.05 \mathrm{~V}$ (Figures $5 \mathrm{~b}$ and $\mathrm{c}$ ), which suggests that the direct growth and attachment of $\mathrm{PB}$ nanocubes on $\mathrm{TiO}_{2}$ NW tips enhance the sensitivity and selectivity. In addition, these data confirm the bio-mimetic enzymatic amplification nature of the $\mathrm{H}_{2} \mathrm{O}_{2}$ catalysis at the $\mathrm{PB}-\mathrm{TiO}_{2}$ antenna NW electrodes. The longterm stability of $\mathrm{PB}-\mathrm{TiO}_{2}$ antenna NW electrodes is exemplified by repeating cyclic voltammetry cycles at different bias voltages. The $\mathrm{PB}-\mathrm{TiO}_{2}$ antenna maintains $95 \%$ of its initial signal responses, even after 1000 cycles (Figure 5d), which is much more sensitive and stable than pristine $\mathrm{TiO}_{2} \mathrm{NWs}$ and $\mathrm{TiO}_{2}$ NWs post-modified with $\mathrm{PB}$, which is excellent for long-term signal monitoring (Figures $5 \mathrm{e}$ and $\mathrm{f}$ ).

The amperometric measurement is further investigated by determining the electrocatalytic activity of the $\mathrm{PB}-\mathrm{TiO}_{2}$ antenna NWs for $\mathrm{H}_{2} \mathrm{O}_{2}$. A substantial cathodic current change is observed at the $\mathrm{PB}-\mathrm{TiO}_{2}$ antenna NW electrodes at $-50 \mathrm{mV}$ when $25 \mu \mathrm{M}$ of $\mathrm{H}_{2} \mathrm{O}_{2}$ is introduced in the buffer, whereas essentially no response is obtained at the pristine $\mathrm{TiO}_{2}$ NWs under otherwise similar conditions (Figure $5 \mathrm{~g}$ ). The contribution of the observed anodic current to the catalysis of $\mathrm{H}_{2} \mathrm{O}_{2}$ is confirmed by adding catalase, ${ }^{10,32}$ a selective scavenger of $\mathrm{H}_{2} \mathrm{O}_{2}$, into the solution with $\mathrm{H}_{2} \mathrm{O}_{2}$. A large decrease in the cathodic current to essentially the background level is observed, which indicates that the signal response can be ascribed to the catalysis of $\mathrm{H}_{2} \mathrm{O}_{2}$ by the $\mathrm{PB}-\mathrm{TiO}_{2}$ antenna NW electrodes.

Amperometric responses of the $\mathrm{PB}-\mathrm{TiO}_{2}$ antenna NWs with successive addition of $\mathrm{H}_{2} \mathrm{O}_{2}$ are conducted at the optimized potential of $-50 \mathrm{mV}$. The stepwise current signal correlates well with each addition of $\mathrm{H}_{2} \mathrm{O}_{2}$, whereas an almost negligible current response is observed for the pristine $\mathrm{TiO}_{2} \mathrm{NWs}$ (Figure 5h). The calibration plot of the current change obtained at the $\mathrm{PB}-\mathrm{TiO}_{2}$ antenna NWs with the $\mathrm{H}_{2} \mathrm{O}_{2}$ concentration is summarized (Figure 5i), and the analytical performance of the $\mathrm{PB}-\mathrm{TiO}_{2}$ antenna NW-based $\mathrm{H}_{2} \mathrm{O}_{2}$ biosensor at the optimum conditions is listed in Supplementary Table S1. Other previously reported $\mathrm{H}_{2} \mathrm{O}_{2}$ biosensors based on $\mathrm{TiO}_{2}$ or titanate nanostructures are also listed in Supplementary Table $\mathrm{S} 1$ for comparison. The $\mathrm{PB}-\mathrm{TiO}_{2}$ antenna NWs exhibit an excellent sensor performance, which includes their higher selectivity, wider linear detection range and lower detection limit. Specifically, the dynamic linear range of $10^{-8}$ to $10^{-5} \mathrm{M}$ to detect $\mathrm{H}_{2} \mathrm{O}_{2}$ at the applied potential of $-50 \mathrm{mV}$ is significantly wider than those obtained in previous $\mathrm{H}_{2} \mathrm{O}_{2}$ biosensing interfaces ${ }^{33,34}$ and fulfills the requirement of realtime, long-term tracking of an $\mathrm{H}_{2} \mathrm{O}_{2}$ concentration (Figure 5i). Moreover, the $\mathrm{PB}-\mathrm{TiO}_{2}$ antenna NW biosensors can be tested and stored at room temperature and can be repeatedly tested for over 180 days without substantial degradation (Supplementary Figure S10), which suggests the high stability of the $\mathrm{PB}-\mathrm{TiO}_{2}$ antenna NW electrodes.

\section{Cell culture and extracellular $\mathrm{H}_{2} \mathrm{O}_{2}$ sensing}

The capability of $\mathrm{PB}-\mathrm{TiO}_{2}$ antenna NW electrodes for direct growth of cells and extracellular $\mathrm{H}_{2} \mathrm{O}_{2}$ detection is further demonstrated. The uniform coverage of $\mathrm{PB}$ nanocubes offers an excellent substrate for 
a

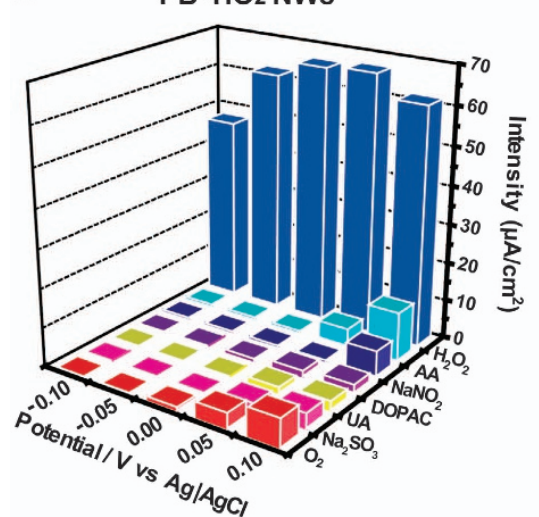

d

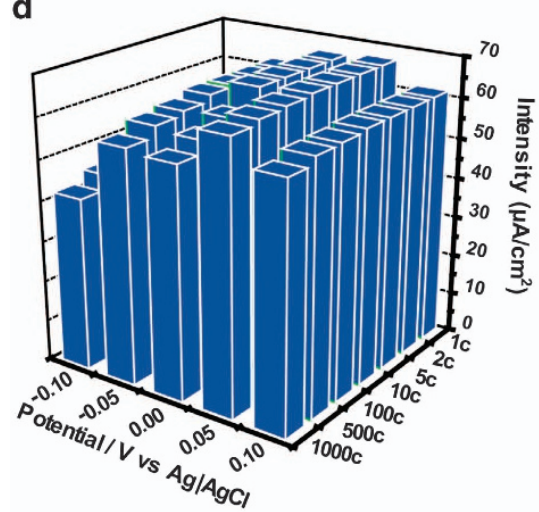

g

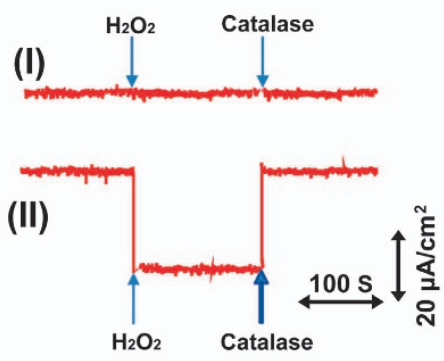

b

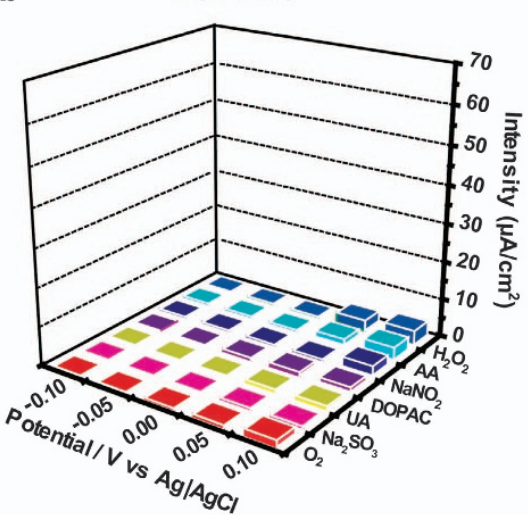

e

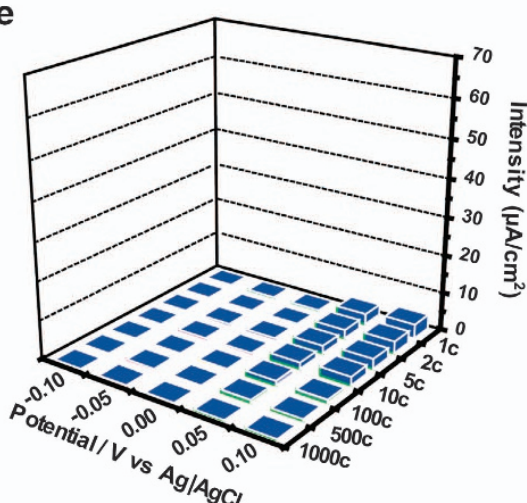

h

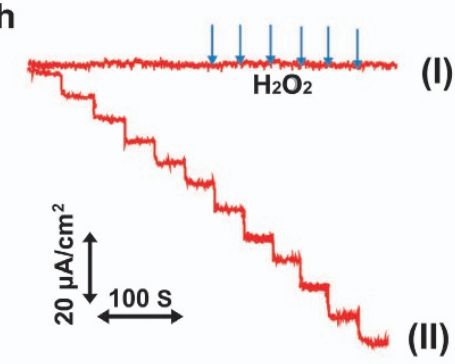

c $\mathrm{TiO}_{2} \mathrm{NWs}+\mathrm{PB}$

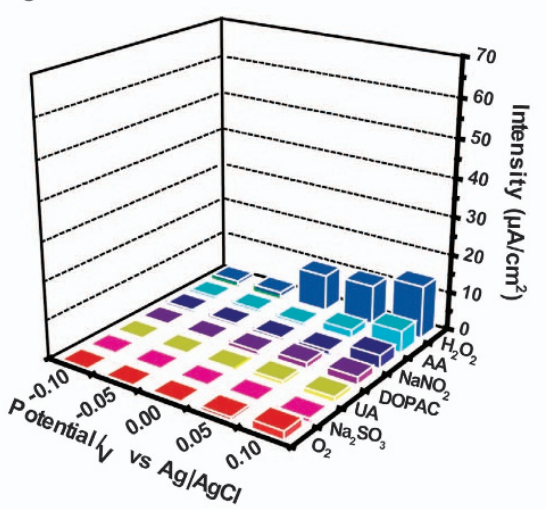

f
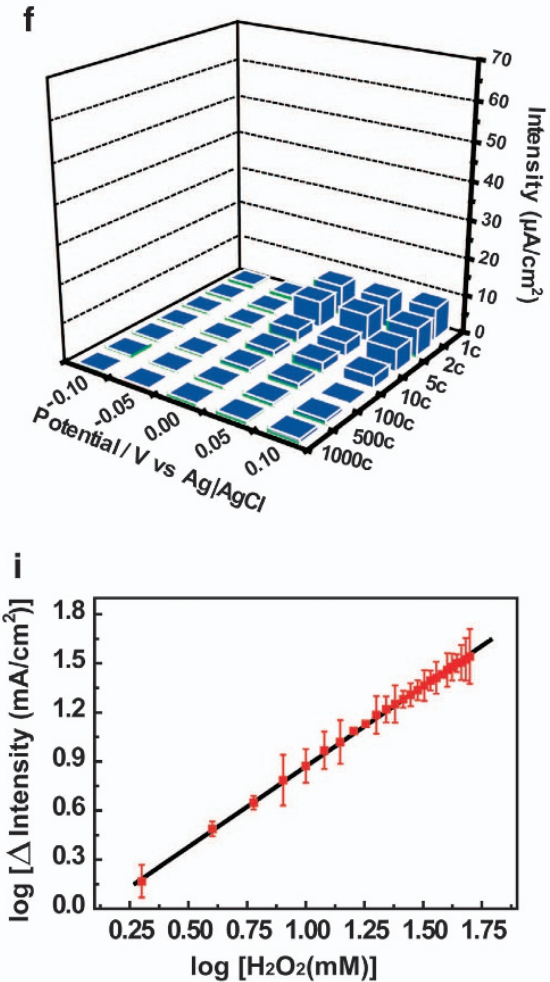

Figure 5 The selectivity, sensitivity, stability and detection range of bio-mimetic Prussian blue (PB)- $\mathrm{TiO}_{2}$ nanowire (NW) antenna arrays. (a-c) The selectivity, sensitivity and (d-f) stability profile of the present $\mathrm{PB}_{-\mathrm{TiO}}$ NW (a,d) electrodes obtained at different applied potentials: $-0.10,-0.05,0.00$, 0.05 and $0.10 \mathrm{~V}$ versus $\mathrm{Ag} / \mathrm{AgCl}$. The $\mathrm{TiO}_{2} \mathrm{NWs}(\mathbf{b}, \mathbf{e})$ and traditional post-modified $\mathrm{PB}$ nanocrystals on $\mathrm{TiO}_{2} \mathrm{NW}$ (c,f) electrodes were used as control experiments. (g) Amperometric responses obtained at the (i) blank $\mathrm{TiO}_{2} \mathrm{NWs}$ and (ii) $\mathrm{PB}^{-\mathrm{TiO}_{2}} \mathrm{NWs}$ electrode in $50 \mathrm{~mm}$ phosphate buffer saline (PBS) $\left(\mathrm{pH}\right.$ of 6.0) containing $100 \mathrm{~mm}$ glucose at the applied potential of $0.0 \mathrm{~V}$ versus $\mathrm{Ag} / \mathrm{AgCl}$ with the addition of the final concentration of $25 \mu \mathrm{M} \mathrm{H}_{2} \mathrm{O}_{2}$ and $500 \mathrm{U} \mathrm{ml}^{-1}$ catalase. (h) Typical amperometric responses of (i) blank $\mathrm{TiO}_{2} \mathrm{NWs}$ and (ii) $\mathrm{PB}-\mathrm{TiO}_{2} \mathrm{NWs}$ to successive additions of $10 \mu \mathrm{M} \mathrm{H} \mathrm{H}_{2} \mathrm{O}_{2}$ at an applied potential of $-0.05 \mathrm{~V}$ versus $\mathrm{Ag} \mid \mathrm{AgCl}$ in $50 \mathrm{~mm} \mathrm{PBS}\left(\mathrm{pH}\right.$ of 6.0). (i) Log-response curve of steady-state currents obtained at the PB-TiO ${ }_{2} \mathrm{NW}$ electrode against concentrations of $\mathrm{H}_{2} \mathrm{O}_{2}$.

cell attachment and growth, which can subsequently produce $\mathrm{H}_{2} \mathrm{O}_{2}$ via different cell functions (Figure 6a). ${ }^{35-37}$ The fluorescence images of HeLa cells grown on top of the $\mathrm{PB}-\mathrm{TiO}_{2}$ antenna NWs clearly confirm a good coverage of cells on the NWs (Figure 6b). The cell viability is measured by [3-(4,5-dimethylthiazol-2-yl)-2,5-diphenyltetrazolium bromide] (MTT) in a Nun Immune Omni Tray (Angle Nun International, Rochester, NY, USA; Experimental Section in Supporting Information, Supplementary Figures S11-S13), which shows that a high HeLa cell viability $(>80 \%)$ is maintained for growth for up to $5 \mathrm{~h}$ (Figure $6 \mathrm{c}$ ). The measured amperometric responses obtained at the bio-interface between the $\mathrm{PB}-\mathrm{TiO}_{2}$ antenna
NWs and HeLa cells are $50 \mathrm{~mm}$ PBS ( $\mathrm{pH}$ of 6.0 ) at an applied potential of $-50 \mathrm{mV}$ versus $\mathrm{Ag} \mid \mathrm{AgCl}$ (Figure 6c). When $50 \mathrm{~mm}$ of PMA is injected into the HeLa cell-NW assay, an increase in the cathodic current is observed (Figure 6d). This phenomenon is attributed to the effect of PMA for inducing $\mathrm{H}_{2} \mathrm{O}_{2}$ production from the cells. ${ }^{10}$ An anodic current increase of $\sim 32.5 \mu \mathrm{A}$ is obtained in $15 \mathrm{~s}$, which is similar to the time scale reported previously. ${ }^{38}$ No response is observed at the bare $\mathrm{TiO}_{2} \mathrm{NWs}$ with the same addition of PMA. In addition, the injection of the catalase solution $\left(300 \mathrm{U} \mathrm{ml}^{-1}\right.$ in PBS) reduces the current level to almost the background current level; catalase is known to inhibit the PMA function. ${ }^{10}$ Accordingly, 
a
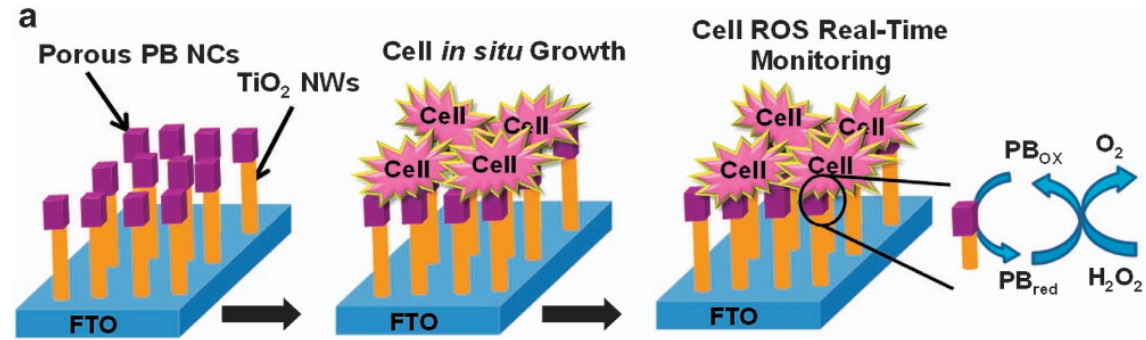

b
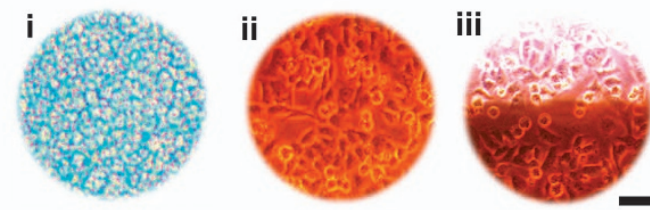

d

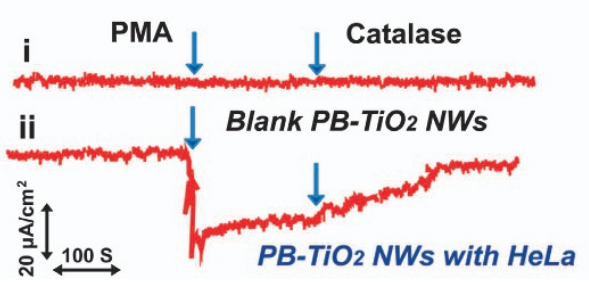

C

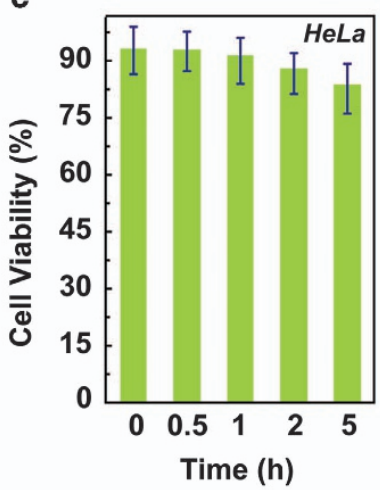

Figure 6 Ultra-sensitive bio-interface based on bio-mimetic antenna Prussian blue (PB)- $\mathrm{TiO}_{2}$ nanowire (NW) arrays. (a) Schematic illustration of the PB- $\mathrm{SiO}_{2}$ NW arrays bio-interface for in-situ living cell culture and real-time three-dimensional recognition and biosensing. (b) Fluorescence microscopic images of (i) $\mathrm{PB}-\mathrm{TiO}_{2} \mathrm{NWs}$, (ii) $\mathrm{PB}-\mathrm{TiO}_{2} \mathrm{NWs}$ with in situ-cultured Hela cells, and (iii) the interface of $\mathrm{PB}^{-\mathrm{TiO}_{2}} \mathrm{NWs}$ and culture dish with in situ-cultured Hela cells (12 h). The scale bar is $50 \mu \mathrm{m}$ for (i-iii). (c) Cell viability of cells cultured on $\mathrm{PB}^{-\mathrm{TiO}_{2}}$ NWs with the amount of testing time. (d) Amperometric responses obtained at the (i) blank $\mathrm{PB}-\mathrm{TiO}_{2} \mathrm{NWs}$ and (ii) $\mathrm{PB}-\mathrm{TiO}_{2} \mathrm{NWs}$ with HeLa cell incubation. The measurement was performed in $50 \mathrm{~mm}$ phosphate buffer saline ( $\mathrm{pH}$ of 6.0) that contained $100 \mathrm{~mm}$ glucose at the applied potential of $-0.05 \mathrm{~V}$ versus $\mathrm{Ag} / \mathrm{AgCl}$ after the final injection concentrations of $50 \mathrm{~mm}$ Phorbol 12 myristate-3-acetate (PMA) and $300 \mathrm{U} \mathrm{ml}^{-1}$ catalase.

the increase in cathodic current at the $\mathrm{PB}-\mathrm{TiO}_{2}$ antenna NW biointerface located near the cells is ascribed to the enzymatic reduction of $\mathrm{H}_{2} \mathrm{O}_{2}$, which is effectively mediated by the $\mathrm{PB}$ nanocubes grown on the $\mathrm{TiO}_{2}$ NWs interface.

The much enhanced sensitivity of the bio-mimetic $\mathrm{PB}-\mathrm{TiO}_{2}$ antenna NWs is attributed to the unique bio-inspired head/arm heterostructure, in which intimate contact between the $\mathrm{PB}$ nanocube heads and the $\mathrm{TiO}_{2} \mathrm{NW}$ arms can create synergistic properties of both components. The porous PB nanocubes offer a robust substrate for site-selective cell adhesion and cultivation of living cells because the porous nanocubes exhibit high selectivity and bioaffinity toward cells and have excellent biostability under the cell culture adhesion condition (up to $108 \mathrm{~h}$ ) (Supplementary Figure S14). Furthermore, the porous nanocrystals can also serve as long-term stable and sensitive sensing elements for $\mathrm{H}_{2} \mathrm{O}_{2}$ due to their inherent bio-mimetic enzymatic activity, high surface area and 3D stereo space-based signal molecules for touching and recognition. In addition, compared with conventional planar PB-covered electrochemical interfaces, ${ }^{39,40}$ the electrocatalytic activity is enhanced at the $\mathrm{PB}-\mathrm{TiO}_{2}$ antenna NW biointerfaces due to the rapid charge transport realized by the onedimensional $\mathrm{TiO}_{2} \mathrm{NW}$ structure. Thus, this $\mathrm{PB}-\mathrm{TiO}_{2}$ antenna NW demonstrates a new sensing platform to reliably and durably detect extracellular molecules.

\section{CONCLUSIONS}

In summary, a bio-mimetic $\mathrm{PB}-\mathrm{TiO}_{2}$ antenna NW array-based biointerface is demonstrated for the first time as an excellent structure that can recognize $3 \mathrm{D}$ signal molecules and that can be used for biosensing. Living cell adhesion and in-situ cultivation on $\mathrm{PB}-\mathrm{TiO}_{2}$ antennas, which integrates with sensitive real-time monitoring of cellular messenger molecules, are realized by the dual-functional $\mathrm{PB}$ nanocube heads and $\mathrm{TiO}_{2} \mathrm{NW}$ arms. The optimized $\mathrm{PB}-\mathrm{TiO}_{2}$ antenna NW biointerfaces exhibit a remarkable sensing performance in detecting $\mathrm{H}_{2} \mathrm{O}_{2}$ with a high sensitivity and selectivity, a broad detection range from $10^{-8}$ to $10^{-5} \mathrm{M}$, a low detection limit down to $20 \mathrm{~nm}$ and a short response time that is within $5 \mathrm{~s}$. In addition, biomimetic PB nanocrystals are stably anchored on the $\mathrm{TiO}_{2} \mathrm{NWs}$ and can maintain long-term biocatalytic activity (up to $\sim 180$ days). The capability of the $\mathrm{PB}-\mathrm{TiO}_{2}$ antenna NW biointerfaces in determining extracellular $\mathrm{H}_{2} \mathrm{O}_{2}$ released from human tumor cells is further demonstrated. This work not only provides a method for 3D interface recognition and biosensing on the hierarchical bio-mimetic nanostructured semiconductors but also suggests a general approach for durable, reliable biomolecule detection in biological systems.

\section{CONFLICT OF INTEREST}

The authors declare no conflict of interest.

\section{ACKNOWLEDGEMENTS}

We thank the following funding agencies for supporting this work: the National Key Basic Research Program of China (2013CB934104, 2012CB224805), the NSF of China (20890123, 21322311, and 21071033), the Program for New Century Excellent Talents in University (NCET-10-0357), the Program for Professor of Special Appointment (Eastern Scholar) at the Shanghai Institutions of Higher Learning and the Deanship of Scientific Research of the King Saud University (IHCRG\#14-102) and the Shanghai Science and Technology Municipality (14JC1490500). BK and JT thank the 
Scholarship Award for Excellent Doctoral Student granted by the Ministry of Education of China and the Interdisciplinary Outstanding Doctoral Research Funding of the Fudan University.

1 Schutz, S., Weissbecker, B., Hummel, H. E., Apel, K.-H., Schmitz, H. \& Bleckmann, H. Insect antenna as a smoke detector. Nature 398, 298-299 (1999).

2 Cayirlioglu, P., Kadow, I. G., Zhan, X., Okamura, K., Suh, G. S., Gunning, D., Lai, E. C. \& Zipursky, S. L. Hybrid neurons in a microRNA mutant are putative evolutionary intermediates in insect $\mathrm{CO}_{2}$ sensory systems. Science 319, 1256-1260 (2008).

3 Pruneanu, S., Pogacean, F., Biris, A. R., Ardelean, S., Canpean, V., Blanita, G., Dervishi, E. \& Biris, A. S. Novel graphene-gold nanoparticle modified electrodes for the high sensitivity electrochemical spectroscopy detection and analysis of carbamazepine. J. Phys. Chem. C 115, 23387-23394 (2011).

4 Eu, J. P., Sun, J., Xu, L., Stamler, J. S. \& Meissner, G. The skeletal muscle calcium release channel: coupled $\mathrm{O}_{2}$ sensor and NO signaling functions. Cell 102, 499-509 (2000).

5 Flavahan, W. A., Wu, Q., Hitomi, M., Rahim, N., Kim, Y., Sloan, A. E., Weil, R. J., Nakano, I., Sarkaria, J. N. \& Stringer, B. W. Brain tumor initiating cells adapt to restricted nutrition through preferential glucose uptake. Nat. Neurosci. 16, 1373-1382 (2013)

6 Morgan, B., Ezeriņa, D., Amoako, T. N., Riemer, J., Seedorf, M. \& Dick, T. P. Multiple glutathione disulfide removal pathways mediate cytosolic redox homeostasis. Nat. Chem. Biol. 9, 119-125 (2012).

7 Zhou, S., Narukami, T., Masuo, S., Shimizu, M., Fujita, T., Doi, Y., Kamimura, Y. \& Takaya, N. NO-inducible nitrosothionein mediates NO removal in tandem with thioredoxin. Nat. Chem. Biol. 9, 657-663 (2013).

8 Otterbein, L. E., Bach, F. H., Alam, J., Soares, M., Lu, H. T., Wysk, M., Davis, R. J., Flavell, R. A. \& Choi, A. M. Carbon monoxide has anti-inflammatory effects involving the mitogen-activated protein kinase pathway. Nat. Med. 6, 422-428 (2000).

9 Lin, V. S., Lippert, A. R. \& Chang, C. J. Cell-trappable fluorescent probes for endogenous hydrogen sulfide signaling and imaging $\mathrm{H}_{2} \mathrm{O}_{2}$-dependent $\mathrm{H}_{2} \mathrm{~S}$ production. Proc. Natl Acad. Sci. USA 110, 7131-7135 (2013)

10 Luo, Y., Liu, H., Rui, Q. \& Tian, Y. Detection of extracellular $\mathrm{H}_{2} \mathrm{O}_{2}$ released from human liver cancer cells based on $\mathrm{TiO}_{2}$ nanoneedles with enhanced electron transfer of cytochrome c. Anal. Chem. 81, 3035-3041 (2009).

11 Ferlay, S., Mallah, T., Ouahes, R., Veillet, P. \& Verdaguer, M. A room-temperature organometallic magnet based on Prussian blue. Nature 378, 701-703 (1995).

$12 \mathrm{Li}, \mathrm{J}$., Li, Y., Zhang, Y. \& Wei, G. Highly sensitive molecularly imprinted electrochemical sensor based on the double amplification by an inorganic prussian blue catalytic polymer and the enzymatic effect of glucose oxidase. Anal. Chem. 84, 1888-1893 (2012).

13 Nossol, E. \& Zarbin, A. J. A simple and innovative route to prepare a novel carbon nanotube/prussian blue electrode and its utilization as a highly sensitive $\mathrm{H}_{2} \mathrm{O}_{2}$ amperometric sensor. Adv. Funct. Mat. 19, 3980-3986 (2009).

14 Zhu, A., Luo, Y. \& Tian, Y. Plasmon-induced enhancement in analytical performance based on gold nanoparticles deposited on $\mathrm{TiO}_{2}$ film. Anal. Chem. 81, 7243-7247 (2009).

15 Baker, M. Tissue models: a living system on a chip. Nature 471, 661-665 (2011).

16 Schwille, P. Bottom-up synthetic biology: engineering in a Tinkerer's world. Science 333, 1252-1254 (2011)

17 Liu, X., Chen, L., Liu, H., Yang, G., Zhang, P., Han, D., Wang, S. \& Jiang, L. Bio inspired soft polystyrene nanotube substrate for rapid and highly efficient breast cancer-cell capture. Asia Mat. 5, e63 (2013).

18 Tian, B., Liu, J., Dvir, T., Jin, L., Tsui, J. H., Qing, Q., Suo, Z., Langer, R., Kohane, D. S. \& Lieber, C. M. Macroporous nanowire nanoelectronic scaffolds for synthetic tissues. Nat. Mater. 11, 986-994 (2012).

19 Kim, D.-H., Lu, N., Ghaffari, R. \& Rogers, J. A. Inorganic semiconductor nanomaterials for flexible and stretchable bio-integrated electronics. Asia Mat. 4, e15 (2012).

20 Hochbaum, A. I. \& Yang, P. Semiconductor nanowires for energy conversion. Chem. Rev. 110, 527-546 (2009).

21 Solanki, P. R., Kaushik, A., Agrawal, V. V. \& Malhotra, B. D. Nanostructured metal oxide-based biosensors. Asia Mat. 3, 17-24 (2011).

$22 \mathrm{Xu}, \mathrm{M}$., Da, P., Wu, H., Zhao, D. \& Zheng, G. Controlled Sn-doping in $\mathrm{TiO}_{2}$ nanowire photoanodes with enhanced photoelectrochemical conversion. Nano. Lett. 12, 1503-1508 (2012)
23 Tang, J., Kong, B., Wang, Y., Xu, M., Wang, Y., Wu, H. \& Zheng, G. Photoelec trochemical detection of glutathione by $\mathrm{IrO}_{2}-\mathrm{Hemin}-\mathrm{TiO}_{2}$ nanowire arrays. Nano. Lett. 13, 5350-5354 (2013).

24 Guo, W., Xu, C., Wang, X., Wang, S., Pan, C., Lin, C. \& Wang, Z. L. Rectangular bunched rutile $\mathrm{TiO}_{2}$ nanorod arrays grown on carbon fiber for dye-sensitized solar cells. J. Am. Chem. Soc. 134, 4437-4441 (2012).

25 Wang, T., Fu, Y., Bu, L., Qin, C., Meng, Y., Chen, C., Ma, M., Xie, Q. \& Yao, S. Facile synthesis of prussian blue-filled multiwalled carbon nanotubes nanocomposites: exploring filling/electrochemistry/mass-transfer in nanochannels and cooperative biosensing mode. J. Phys. Chem. C 116, 20908-20917 (2012).

26 Zhang, X.-Q., Gong, S.-W., Zhang, Y., Yang, T., Wang, C.-Y. \& Gu, N. Prussian blue modified iron oxide magnetic nanoparticles and their high peroxidase-like activity. J. Mat. Chem. 20, 5110-5116 (2010).

27 Song, Y.-Y., Jia, W. Z., Li, Y., Xia, X. H., Wang, Q. J., Zhao, J. W. \& Yan, Y. D. Synthesis and patterning of prussian blue nanostructures on silicon wafer via galvanic displacement reaction. Adv. Funct. Mat. 17, 2808-2814 (2007).

28 Zhao, J., Zhu, X., Li, T. \& Li, G. Self-assembled multilayer of gold nanoparticles for amplified electrochemical detection of cytochrome c. Analyst 133, 1242-1245 (2008).

29 Dai, Z., Liu, S. \& Ju, H. Direct electron transfer of cytochrome $c$ immobilized on a NaY zeolite matrix and its application in biosensing. Electrochim. Acta. 49, 2139-2144 (2004).

30 Ju, H., Liu, S., Ge, B., Lisdat, F. \& Scheller, F. W. Electrochemistry of cytochrome c immobilized on colloidal gold modified carbon paste electrodes and its electrocatalytic activity. Electroanalysis 14, 141-147 (2002).

$31 \mathrm{Li}$, X., Liu, Y., Zhu, A., Luo, Y., Deng, Z. \& Tian, Y. Real-time electrochemical monitoring of cellular $\mathrm{H}_{2} \mathrm{O}_{2}$ integrated with in situ selective cultivation of living cells based on dual functional protein microarrays at $\mathrm{Au}-\mathrm{TiO}_{2}$ surfaces. Anal. Chem. 82, 6512-6518 (2010).

32 Mesquita, A., Weinberger, M., Silva, A., Sampaio-Marques, B., Almeida, B., Leão, C., Costa, V., Rodrigues, F., Burhans, W. C. \& Ludovico, P. Caloric restriction or catalase inactivation extends yeast chronological lifespan by inducing $\mathrm{H}_{2} \mathrm{O}_{2}$ and superoxide dismutase activity. Proc. Natl Acad. Sci. USA 107, 15123-15128 (2010).

$33 \mathrm{Liu}$, H., Tian, Y. \& Xia, P. Pyramidal, rodlike, spherical gold nanostructures for direct electron transfer of copper, zinc-superoxide dismutase: application to superoxide anion biosensors. Langmuir 24, 6359-6366 (2008).

34 Zhang, L., Zhang, Q. \& Li, J. Layered titanate nanosheets intercalated with myoglobin for direct electrochemistry. Adv. Funct. Mat. 17, 1958-1965 (2007).

35 Root, R. K. \& Metcalf, J. A. $\mathrm{H}_{2} \mathrm{O}_{2}$ release from human granulocytes during phagocytosis: relationship to superoxide anion formation and cellular catabolism of $\mathrm{H}_{2} \mathrm{O}_{2}$ : studies with normal and cytochalasin B-treated cells. J. Clin. Invest. 60, 1266 (1977).

36 Wang, D., Youngson, C., Wong, V., Yeger, H., Dinauer, M. C., De Miera, E. V.-S. Rudy, B. \& Cutz, E. NADPH-oxidase and a hydrogen peroxide-sensitive $\mathrm{K}^{+}$channel may function as an oxygen sensor complex in airway chemoreceptors and small cel lung carcinoma cell lines. Proc. Natl Acad. Sci. USA 93, 13182-13187 (1996).

37 Pei, Z.-M., Murata, Y., Benning, G., Thomine, S., Klüsener, B., Allen, G. J., Grill, E. \& Schroeder, J. I. Calcium channels activated by hydrogen peroxide mediate abscisic acid signalling in guard cells. Nature 406, 731-734 (2000).

38 Zhu, A., Tian, Y., Liu, H. \& Luo, Y. Nanoporous gold film encapsulating cytochrome $c$ for the fabrication of a $\mathrm{H}_{2} \mathrm{O}_{2}$ biosensor. Biomaterials 30, 3183-3188 (2009).

39 Karyakin, A. A., Karyakina, E. E. \& Gorton, L. Amperometric biosensor for glutamate using Prussian blue-based 'artificial peroxidase' as a transducer for hydrogen peroxide. Anal. Chem. 72, 1720-1723 (2000).

40 Moscone, D., D'ottavi, D., Compagnone, D., Palleschi, G. \& Amine, A. Construction and analytical characterization of Prussian blue-based carbon paste electrodes and their assembly as oxidase enzyme sensors. Anal. Chem. 73, 2529-2535 (2001).

(c) (1) (2) This work is licensed under a Creative Commons Attribution-NonCommercial-ShareAlike 3.0 Unported License. The images or other third party material in this article are included in the article's Creative Commons license, unless indicated otherwise in the credit line; if the material is not included under the Creative Commons license, users will need to obtain permission from the license holder to reproduce the material. To view a copy of this license, visit http://creativecommons.org/licenses/by-nc-sa/3.0/

Supplementary Information accompanies the paper on the website (http://www.nature.com/am) 